\title{
Ground-based interferometric radar for velocity and calving-rate measurements of the tidewater glacier at Kronebreen, Svalbard
}

\author{
C. ROLSTAD, ${ }^{1}$ R. NORLAND ${ }^{2}$ \\ ${ }^{1}$ Department of Mathematical Sciences and Technology, The Norwegian University of Life Sciences, PO Box 5003, \\ NO-1432 Ass, Norway \\ E-mail: cecilie.rolstad@umb.no \\ ${ }^{2}$ ISPAS as, PO Box 219, 1501 Moss, Norway
}

\begin{abstract}
This paper presents the first attempt to measure the calving rate and flow velocity of the front of a glacier using ground-based high-range resolution interferometric radar at a high temporal rate $(2 \mathrm{~Hz})$. The radar, operating at $5.75 \mathrm{GHz}$, is located $\sim 4 \mathrm{~km}$ from the calving front of Kronebreen, Svalbard. The radar measures a horizontal width of $\sim 700 \mathrm{~m}$ of the front, and a range of $300 \mathrm{~m}$. The latter includes the calving front and $250 \mathrm{~m}$ up-glacier. We find that the glacier surface provides permanent scatterers, so spatially continuous movements at the front and at locations further up-glacier can be tracked. For $\sim 8$ hours we measured a large increase in velocity at the calving front, which extended $30 \mathrm{~m}$ up-glacier, while further up-glacier the velocity was stable $\left(\sim 2.5 \mathrm{~m} \mathrm{~d}^{-1}\right)$ during the entire period. Two large calving events were identified during this survey, removing $25 \mathrm{~m}$ of ice in the radar range direction normal to the ice front. The velocity of the front slowed to a stable $2.5 \mathrm{~m} \mathrm{~d}^{-1}$ after the events. During another data series the velocities were stable $\left(\sim 2.5 \mathrm{~m} \mathrm{~d}^{-1}\right)$ and no calving events were identified. The method is promising for carrying out studies of processes at a calving front, as it provides spatially continuous, high-frequency accurate velocities from a safe distance to the glacier.
\end{abstract}

\section{INTRODUCTION}

Calving is an important process in the mass budget of glaciers. In Antarctica most mass loss is through calving (Bentley and Giovinetto, 1991). In Greenland the importance of calving is less clear but an estimated average of $\sim 50 \%$ of total mass loss through calving is suggested (Bigg, 1999; Reeh and others, 1999). For Arctic tidewater glaciers the calving rate is highly variable, depending on whether the glacier is retreating, advancing or in a steady state. Climatic warming may change the calving rate. Higher supplies of surface meltwater to the bed induce higher velocities, and altered accumulation rates will affect the velocity. As a response to changed velocity, the front position may move to deeper water depths, inducing higher calving rates (Brown and others, 1982; Hansson and Hooke, 2000, 2003). As stated by Oerlemans and Nick (2005), more tidewater glaciers were observed to be retreating than advancing during the last century, so knowledge of the calving process becomes crucial for assessing the mass loss of glaciers and their contribution to global sea level.

Calving processes are not entirely understood. In a review article, Benn and others (2007) classified the calving processes into two groups according to their importance in determining the position of the calving front. First-order control on calving is determined by strain rates due to spatial variations in stress, and second-order controls on calving are the processes occurring in the calving front (e.g. fracture propagation due to stress imbalances, undercutting due to melting at or below the waterline, and bending at the junction of grounded or buoyant parts of the ice). We use Benn and others' (2007) first- and secondorder classification in this paper. The relative importance of first- or second-order processes varies for each glacier. There is also an important discussion on whether calving triggers flow acceleration up-glacier (Hughes, 1986; Meier and Post, 1987; Howat and others, 2005), or whether calving is a passive response to dynamic changes such as flow acceleration and thinning in the upper parts of the glacier (Van der Veen, 1996, 2002; Venteris and others, 1997).

Measurements of calving fronts are sparse due to the dangers connected to fieldwork, so remote-sensing techniques that yield average velocities have been applied. Crevasse tracking is conducted using pairs of optical satellite images (Scambos and others, 1992), aerial photographs (Krimmel, 2001; O'Neel and others, 2005), airborne laser altimetry (Abdalati and Krabill, 1999) and interferometric measurements or speckle tracking with pairs of satellite synthetic aperture radar (SAR) images (Goldstein and others, 1993; Joughin, 2002; Joughin and MacAyeal, 2005; Rignot and Kanagaratnam, 2006). However, near the calving front there may be problems with these methods. In the crevasse-tracking method there can be large changes in the crevasse pattern due to shear or surface melting (Rolstad and others, 1997), and in the interferometric SAR method there can be problems with high speed and loss of coherence in the radar signal due to high shear (Hanssen, 2001). These satellite-based techniques provide average velocities at a low temporal rate, ranging from 1 day to 1 year. Ground-based remote sensing, using terrestrial photogrammetry, has also provided velocity data on calving rates averaged over days, weeks or years (Theakstone and others, 1986; Melvold, 1992; Pfeffer, 2004). Remotely sensed data provide information on surface velocities and thus surface strain rates, and are useful for investigating first-order calving processes. Global positioning system (GPS) measurements provide data at a high temporal rate (seconds) for specific points (Elosegui and others, 2007), though access to the glacier is required and the locations are some hundreds of metres up-glacier from the front. 
Velocity measurements using ground-based radar interferometry may be useful for studying calving processes at high temporal resolution. A ground-based differential interferometric radar is currently used for rock-slide monitoring near the Norwegian fjord Tafjorden (Norland, 2006). The radar has been developed by the company ISPAS as (Norway), and measures corner reflectors mounted on unstable rocks on slopes. Typical variations in the positioning of the reflectors measured at this site are $\sim 3 \mathrm{~mm} \mathrm{~d}^{-1}$. Measurements are made across the fjord at a distance of $3 \mathrm{~km}$ and the variations are mainly due to differences in meteorological conditions. The differential interferometric radar system measures movement with an estimated accuracy of $0.1 \mathrm{~mm}$ (Norland, 2006). A similar ISPAS radar was used in our project on the Kronebreen calving front.

Our goal was to test whether a ground-based interferometric radar system is suitable for measuring the velocity of a calving front. The radar was placed $4 \mathrm{~km}$ from the glacier and measurements extended from the vertical calving front to $\sim 300 \mathrm{~m}$ up-glacier. The measurement interval was every $0.5 \mathrm{~s}(2 \mathrm{~Hz})$ so that speed variations during a single calving event could be resolved. A video camera recorded the calving front to aid radar data interpretation. Several questions were addressed:

Is there an orientation of the antennas that is most favorable?

Are there coherent radar targets (permanent scatterers) on the glacier surface that can be tracked in the radar dataset?

What is the accuracy of the determined velocities?

Is it possible to identify calving events from radar and video data?

Is it possible to measure spatial differences in speed on the vertical calving front and further up-glacier?

Does calving influence the speed of the glacier?

Can the dataset contribute to improved understanding of the second-order calving processes?

The measurements were made on Kronebreen, Svalbard, over 1 week at the end of August/beginning of September 2007. Kronebreen has the second largest drainage area $\left(1375 \mathrm{~km}^{2}\right)$ in Svalbard, covering Holtedalsfonna and Isacsenfonna. It is the fastest glacier in Svalbard, with a velocity up to $3 \mathrm{~m} \mathrm{~d}^{-1}$ near the calving front. Previous measurements of velocities on Kronebreen have been conducted by Pillewizer and Voigt (1968), Melvold (1992), Lefauconnier and others (1994), Rolstad (1995) and Kääb and others (2005).

\section{Interferometric radar measurement}

The measurements were performed using real-aperture antenna interferometric radar. Interferometric radar measurement is a well-proven technique, demonstrated for the first time in 1974 (Graham, 1974). It was later used in a number of different applications either regionally using air- or spaceborne radar for ice-sheet movement detection (Goldstein and others, 1993), digital elevation models (DEMs) (Zebker and Goldstein, 1986), monitoring of volcanoes (Massonnet and others, 1995) and the detection of unstable slopes (Strozzi and others, 2002), or locally as a ground-based fixed installation real-aperture antenna for monitoring, for example, slope movement with reflectors (Norland, 2006).
Interferometric radar measures the phase of an electromagnetic wave scattered back from an object at some distance, $R$. The phase $(\phi)$ varies as a function of the distance and electromagnetic wavelength, $\lambda$ :

$$
\varphi=\frac{4 \pi R}{\lambda}
$$

where the distance

$$
R=\frac{T C_{0}}{2 n(\vec{r}, t)} .
$$

$C_{0}$ is the velocity of light in a vacuum, $T$ is the two-way travel time of the electromagnetic wave from the radar to the measured object, and $n(\vec{r}, t)$ is the spatial and temporal index of refraction. Indirectly, the index of refraction is also a function of atmospheric turbulence due to varying degrees of mixing in the atmosphere. The accuracy of interferometric measurements of scatterers at a large distance is thus dependent on the variation of the refractive index. For example, the variation in measured distance to a reflector at a distance of $2900 \mathrm{~m}$ was $\sim 30 \mathrm{~cm}$ during 1 month in Tafjorden (Norland, 2007). The accuracy can be improved using either differential interferometric measurements to a stable reflector (Norland, 2006), or by estimating the variation of the refractive index using local meteorological data (Norland, 2007).

The advantage of ground-based real-aperture antenna interferometric radar is the high temporal sampling rate combined with accurate relative interferometric range measurements. Thus, it is possible to measure the range variation $(\Delta r)$ of objects using the phase of the reflected electromagnetic wave from a stable scatterer within any of the range cells simultaneously:

$$
\Delta r=\frac{\lambda \Delta \varphi}{4 \pi},
$$

where $\Delta \phi$ is the phase difference between the two measurements. Because the phase is wrapped every $2 \pi$, the interferometric range measurements are folded every $\lambda / 2$, so in order to track point scatterers over larger movements, the phase must be unwrapped.

The measurements on Kronebreen were performed using a frequency-modulated continuous wave (FMCW) at $5.75 \mathrm{GHz}$ (Fig. 1a and d). The distance to the front of the glacier was $\sim 4000 \mathrm{~m}$ and the measured area was 3950-4250 m (Fig. 1b and c). The range resolution was $1 \mathrm{~m}$, and theoretically all $3001 \mathrm{~m}$ range cells can be tracked in the subsequent measurement. However, tracking requires permanent scatterers which are not present for all range cells. The temporal sampling rate was $2 \mathrm{~Hz}$ and the realaperture antenna beamwidth was $\sim 9^{\circ}$. The location of the range cells transverse to the beam direction cannot be determined with this system. In order to monitor variations of the refractive index and verify the radar transmissions, a corner reflector was continuously measured at $108 \mathrm{~m}$. No correction for variation in the refraction index was conducted in this study; however, the variation of the refractive index from the radar to the reflector was extrapolated to assess possible implications on the interferometric measurements of the glacier. The data showed that the measured movement of the glacier was much higher than the small, low-frequency movements due to the variations of the refractive index were. Tests were conducted with horizontal $(\mathrm{H})$ and vertical $(\mathrm{V})$ electromagnetic polarizations (Ulaby, 2006), in the following combinations: $\mathrm{HH}, \mathrm{VV}$ and 


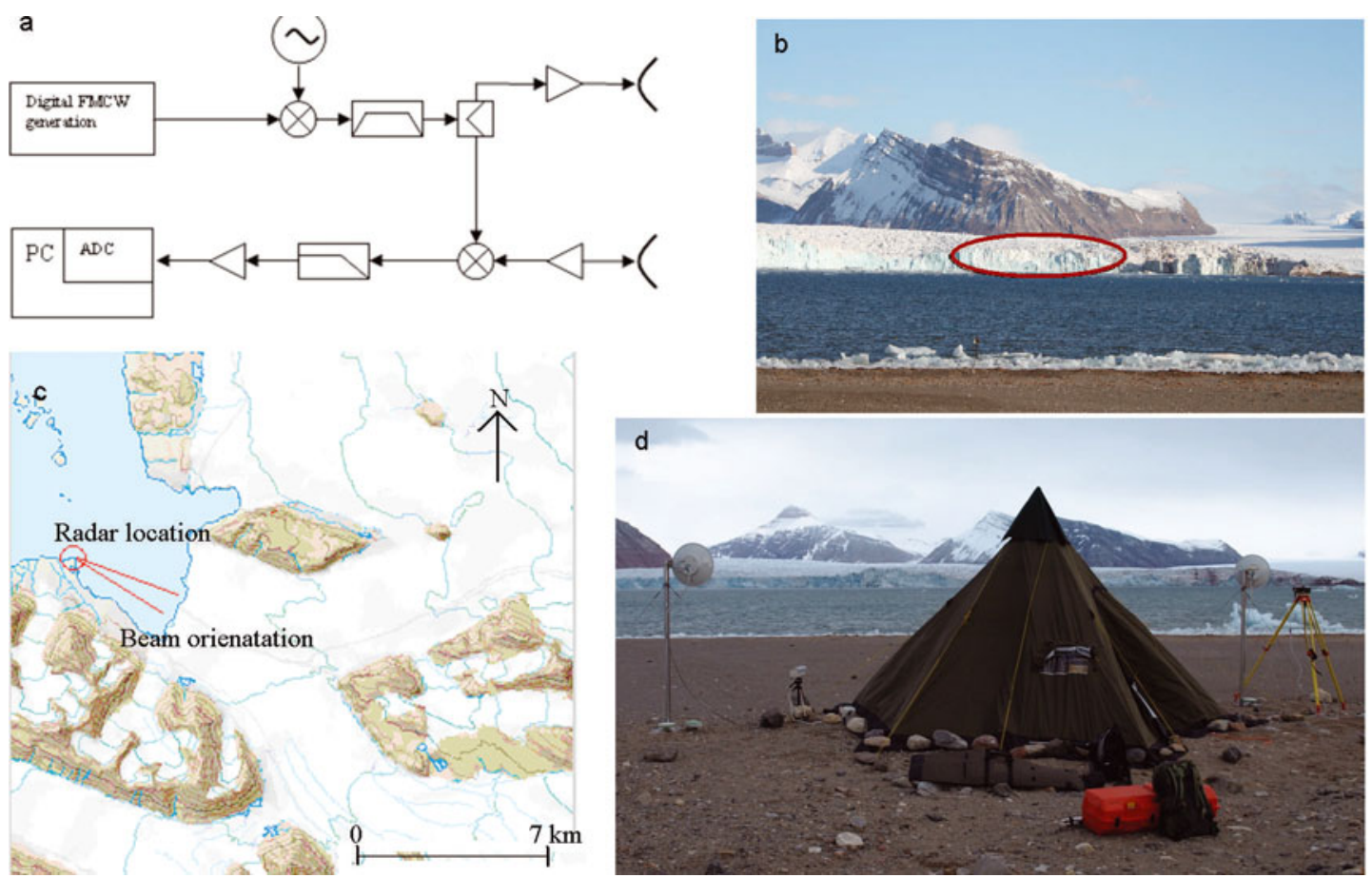

Fig. 1. Location and measurement set-up. (a) Schematic presentation of ISPAS FMCW radar. (b) The ellipse shows the approximate area covered by the radar at the glacier front. (c) Sketch of radar location and beam orientation. (d) Radar antennas and equipment at measurement site.

VH. Video images were recorded every $30 \mathrm{~s}$ to aid interpretation of the radar data. A total of 45 hours of measurements were completed. The radar is schematically presented in Figure 1a.

\section{RESULTS}

\section{Polarizations}

Some rudimentary tests of the backscattering using different polarizations were conducted for $\mathrm{HH}, \mathrm{VH}$ and $\mathrm{VV}$ polarizations, and the intensity of the returned signals is shown in Figure 2. There are strong reflections from the glacier ice for all three polarizations. The green colour from 3950 to $4020 \mathrm{~m}$ is the reflection from the sea and occasionally from floating ice, the yellow and purple band from 4020 to $4080 \mathrm{~m}$ is the vertical glacier front and vertical ice faces in this range further up-glacier, and green colours from 4100 to
$4250 \mathrm{~m}$ illustrate weaker signals from the more horizontal glacier surface further up-glacier.

\section{Velocities}

Figure 3 shows two longer time series of continuous measurements from 29-30 August (22 hours), and from 1 September (11 hours). The strong reflection plotted in yellow and orange from 4020 to $4080 \mathrm{~m}$ is, as in Figure 2, the vertical front. The two data series are measured with different polarizations, which might explain the slightly different appearance of the plotted signal. Note that there is a small gap in the dataset at 30 August near $1500 \mathrm{~h}$. The first hour of the dataset from 1 September appears different from the following data, possibly due to a slight shift in the vertical/horizontal orientation of the antennas.

Some of the permanent scatterers are tracked, and the velocities at these specific ranges are measured. The results for the two periods are shown in Figure 4. Figure 4a
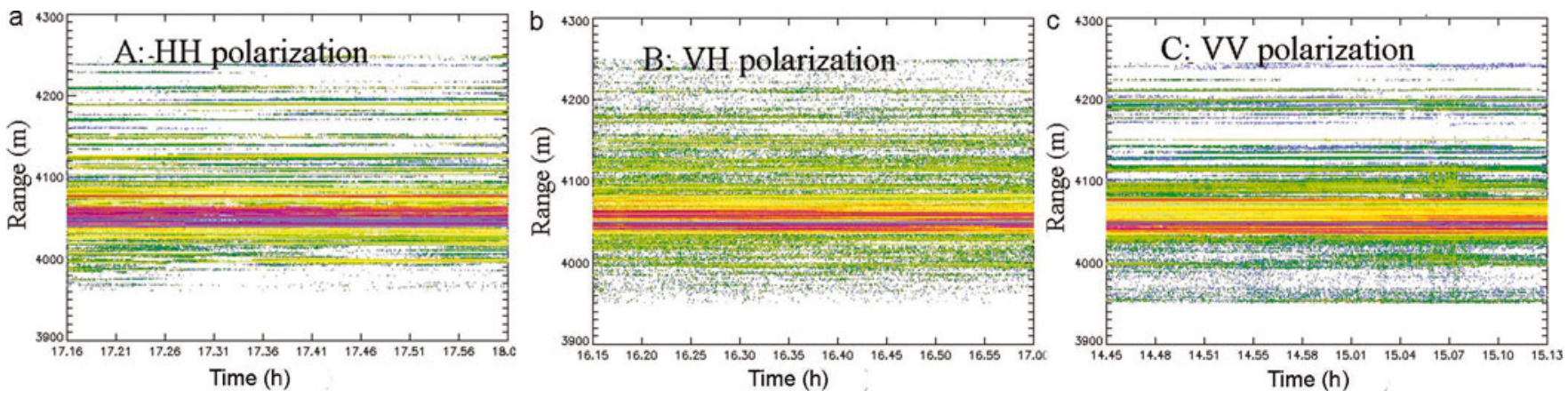

Fig. 2. Intensity of returned signal $(\mathrm{dB})$ during tests of $\mathrm{HH}, \mathrm{VH}$ and $\mathrm{VV}$ polarizations. Colour scale is in arbitrary units. Signal ranging from green (weak) to red (strong). 

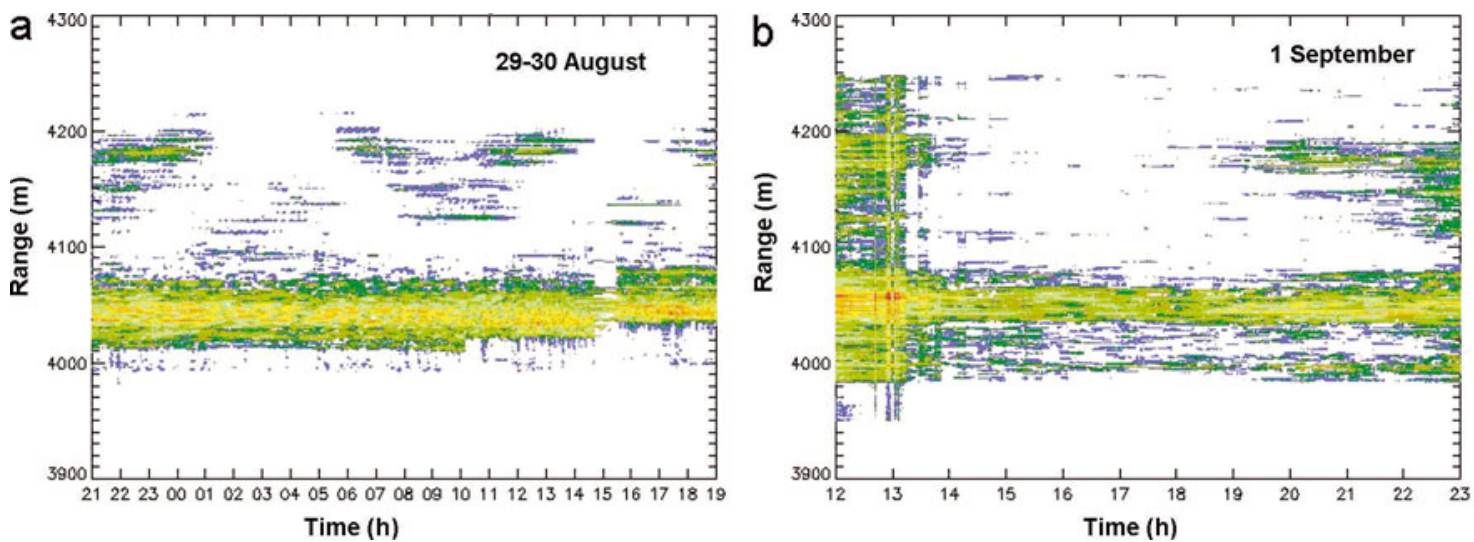

Fig. 3. Amplitude of returned signal $(\mathrm{dB})$. Colour scale is in arbitrary units. Signal ranges from green (weak) to red (strong). (a) Measurements from local time $2100 \mathrm{~h}, 29$ September to $1900 \mathrm{~h}, 30$ August 2007, VV polarization. (b) Measurements from local time 1200-2300 h, 1 September 2007, $\mathrm{HH}$ polarization.

(29-30 August) shows a linear velocity at range $4189 \mathrm{~m}$, $\sim 150 \mathrm{~m}$ up-glacier from the front, of $2.5 \mathrm{~m} \mathrm{~d}^{-1}$ for the entire period. The variations between $2200 \mathrm{~h}$ on 29 August and $0600 \mathrm{~h}$ on 30 August may be noise due to problems with tracking scatterers, as the horizontal positions of the strongest scatterer at the range of $4189 \mathrm{~m}$ vary. At a range of $4042 \mathrm{~m}$, near the front, a linear velocity of $2.5 \mathrm{~m} \mathrm{~d}^{-1}$ is observed until $\sim 0800 \mathrm{~h}$, then the velocity increases until $1440 \mathrm{~h}$. The gap in the data near $1500 \mathrm{~h}$ makes the curve difficult to interpret, but the velocity appears to be stable and linear after $\sim 1530 \mathrm{~h}$, with a small jump at $\sim 1700 \mathrm{~h}$. Figure $4 \mathrm{~b}$ shows the data for 1 September, where the velocity is stable at $2.6 \mathrm{~m} \mathrm{~d}^{-1}$ for the front (range $4041 \mathrm{~m}$ ), and at $2.4 \mathrm{~m} \mathrm{~d}^{-1}, \sim 150 \mathrm{~m}$ up-glacier (range $4189 \mathrm{~m}$ ).

\section{Calving events}

A large calving event occurred on 30 August, at local time 10:09:06. Changes in the vertical calving front are identified in the video images shown in Figure 5. The event is identified in the radar data in Figure 6 . The range to the strong returned signal of the vertical front increases by $\sim 10 \mathrm{~m}$ at the time of the calving, from 4010 to $4020 \mathrm{~m}$.

Visual inspection of Figure $3 a$ shows another major calving event between 1500 and $1600 \mathrm{~h}$ on 30 August. The distance to the strong return signal at the front increased from 4020 to $4035 \mathrm{~m}$. From 1010 to $1600 \mathrm{~h}$ on that day, a total of $25 \mathrm{~m}$ of glacier ice, in the radar range direction, calved off. The range to the calving front increased from 4010 to $4020 \mathrm{~m}$ at $1010 \mathrm{~h}$, then to $4035 \mathrm{~m}$ between 1500 and $1600 \mathrm{~h}$. No major calving events can be identified in the radar data for 1 September (Fig. 3b). The range to the front was stable at $\sim 4035 \mathrm{~m}$, gradually reducing, of course, with the movement of the glacier.

\section{Spatial and temporal variations in velocity from $\mathbf{4 0 0 0}$ to $4200 \mathrm{~m}$}

Between 1340 and $1440 \mathrm{~h}$ on 30 August, high velocities of up to $750 \mathrm{~mm} \mathrm{~h}^{-1}$ were detected near the glacier front (Fig. 7c). These high velocities were limited to the first $30 \mathrm{~m}$ of the glacier, and no significant changes in velocity upglacier of this region were observed. Figure 7 illustrates the increase in velocity down-glacier from a range of $4045 \mathrm{~m}$, which started at $\sim 0800 \mathrm{~h}$ on 30 August, reached a peak near to $1400 \mathrm{~h}$ and returned to normal values by $1700 \mathrm{~h}$. Note that the position of the calving front retreats in these plots due to the two calving events. The velocity at a range of $4042 \mathrm{~m}$ during the whole period is shown in Figure 4a. The increase in velocity starts before the calving events, and returns to normal soon after the calving events.

In Figure $4 \mathrm{~b}$ the velocity is seen to be stable during the entire measurement period on 1 September. Figure 8 shows the spatial variations in velocity for this latter period. The
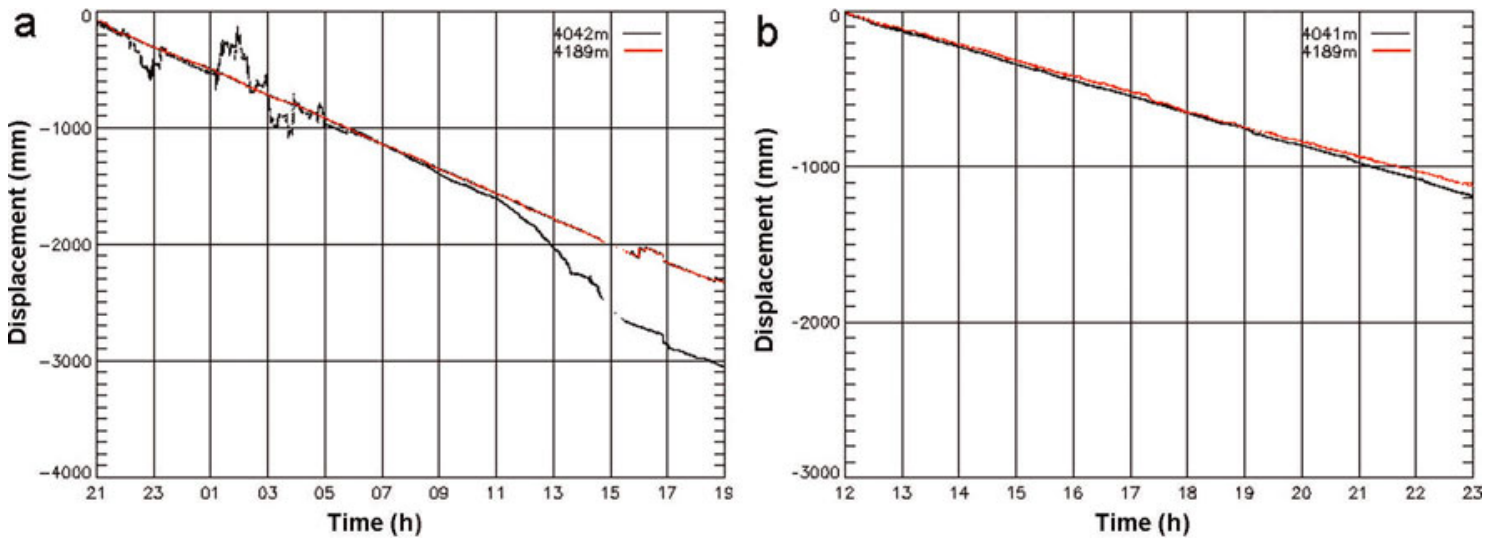

Fig. 4. Movement profiles at specific ranges, tracked from permanent scatters. (a) 29-30 August 2007, VV polarization, range 4042-4189 m. (b) 1 September 2007, HH polarization, range 4041-4189 m. 

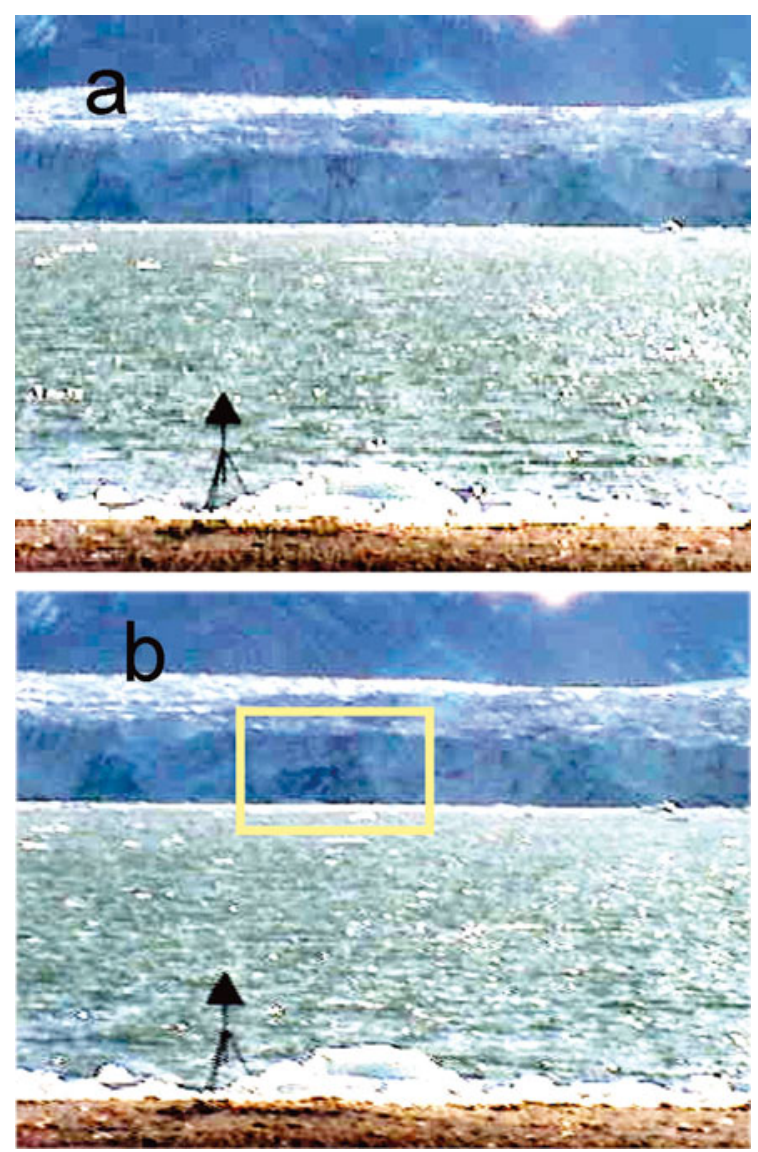

Fig. 5. Video images of the vertical calving front with a $30 \mathrm{~s}$ interval, 30 August 2007, (a) at 10:09:01 $\mathrm{h}$ and (b) at 10:09:31 h. The calving event has occurred in the lower image; note the dark area in the yellow rectangle.

distance to the calving front was at $\sim 4040 \mathrm{~m}$, decreasing with the movement during the day. No large variations in the movement were measured.

\section{DISCUSSION}

Tests with varying polarizations do not indicate a clearly favourable polarization, all polarizations yielding strong reflections. However, Figure 3 shows that it might be an advantage to conduct all measurements during a campaign using the same polarization for comparison of the datasets.

The glacier ice reflects strongly and also provides permanent scatterers that can be tracked. It is clear that there are periods when the positions of the strongest reflectors shift, which introduces noise in the data (Fig. 4a). Figure 7 also shows sharp peaks and troughs that might stem from problems with tracking scatterers. However, these figures also illustrate that there were long periods of stable conditions during which natural reflectors could be tracked. Corner reflectors mounted on the ice, providing a strong backscatter that can be tracked, would of course be a large advantage. However, the results show that this method can be used without such reflectors.

The accuracy of the velocity measurement is dependent on the spatial and temporal variation in the refractive index, movement of antennas due to wind or unstable antenna racks, and whether a scatterer can be tracked. At Kronebreen, a stable reflector was placed on the side of the fjord

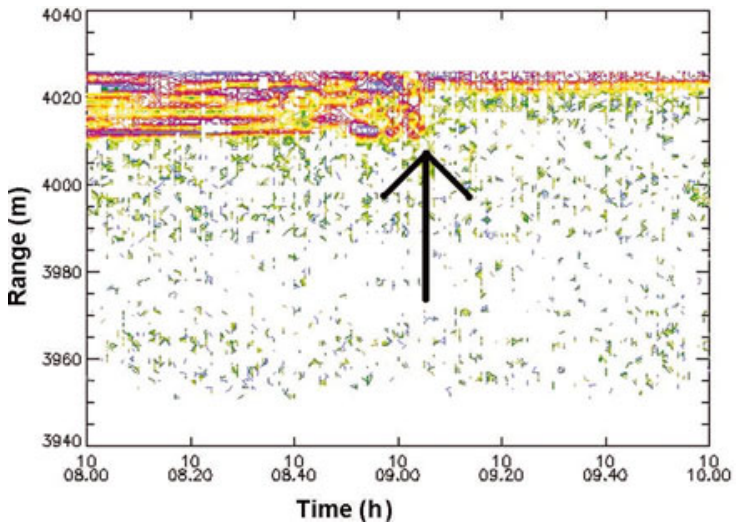

Fig. 6. Amplitude of returned signal $(\mathrm{dB})$ during the calving event at 10:09:06, 30 August 2007, indicated by the arrow. Colour scale is in arbitrary units. Signal ranges from green (weak) to red (strong).

near the instrument to monitor the radar transmissions and variations in the refractivity, but not to correct for variations in the refractivity as was conducted for the rock-slide monitoring in Tafjorden (Norland, 2007). Such corrections could be made from differential measurements to a stable corner reflector on the opposite side of the fjord from the radar, or by using meteorological data to calculate the variation. The latter method is less accurate than the first. Experiments with uncorrected measurements in Tafjorden show a low-frequency deviation of $103 \mathrm{~mm}$ for a measured distance of $2910 \mathrm{~m}$ over 1 month in December-January (Norland, 2007). The meteorological conditions were stable during the fieldwork at Kronebreen, and as the profile in Figure $4 \mathrm{~b}$ shows, the measured velocity was also stable.

When a stable permanent scatterer can be tracked, we assume that the accuracy of the measurements is near the results found for Tafjorden, but possibly less accurate since natural reflectors give a weaker return signal and there might be movement of the antennas. An accuracy of the velocity of some hundreds of $\mathrm{mmd}^{-1}$ is expected, but tests must be conducted to confirm this. The accuracy of the relative velocities between scatterers on the glacier is expected to be good since the variations in the refraction index along some hundreds of metres of the glacier ice are most probably smaller than over the fjord. The accuracy of relative velocities over the glacier is thus expected to be similar to the instantaneous instrument accuracy of interferometric measurements of $\pm 0.1 \mathrm{~mm}$ determined at Tafjorden, at some $\mathrm{mm} \mathrm{d}^{-1}$. A stable corner reflector could be placed at the opposite side of the fjord to correct for variations in the refractive index and thus improve the absolute accuracy. Corner reflectors could also be placed on the glacier to provide strong backscatter for continuous accurate point measurements of velocities.

The measured stable velocities seem to be in general agreement with previous measurements; however, these are not directly comparable since previous measurements do not cover the calving front and also represent average values over different periods. The front position also varies over the years, and has in general been retreating since 1948 (Melvold, 1992). Previous measurements have shown transverse variations in longitudinal velocity, and both seasonal and interannual variations. Kääb and others (2005) have summarized available measurements and show a transverse velocity profile $\sim 1 \mathrm{~km}$ up-glacier from the front, 

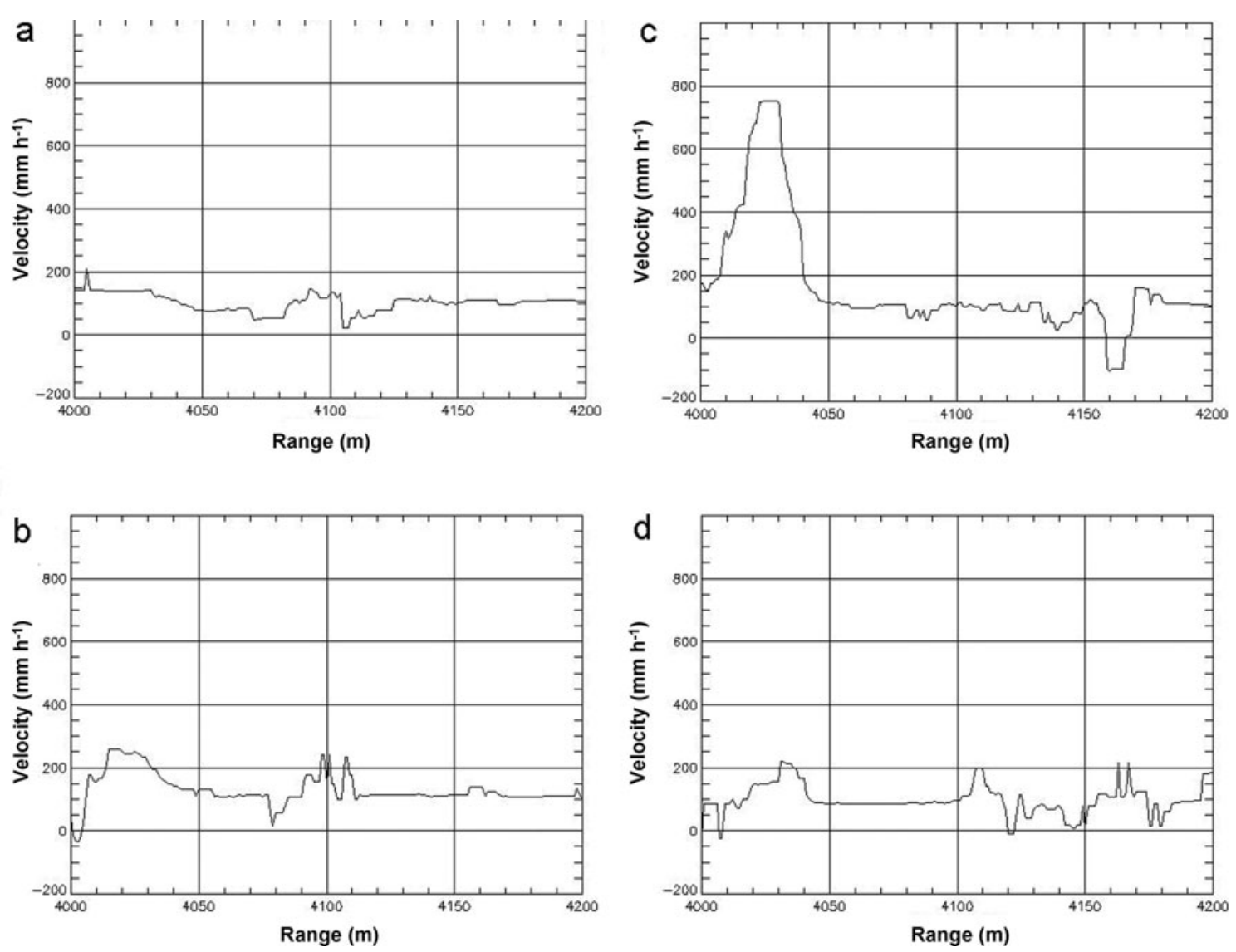

Fig. 7. Spatial variation in a velocity over $4000-4200 \mathrm{~m}$ : (a) $2200-2300 \mathrm{~h}, 29$ August; (b) $0830-0930 \mathrm{~h}, 30$ August; (c) $1340-1440 \mathrm{~h}$, 30 August; and (d) 1700-1800 h, 30 August.

and a longitudinal profile extending down to $\sim 1 \mathrm{~km}$ from the front. Maximum velocities on the transverse profile are 1.4-3.1 $\mathrm{m} \mathrm{d}^{-1}$ (in August 1990 (Melvold, 1992)). Pillewizer and Voigt (1968) measured seasonal variations in velocities, and found a maximum speed at the end of June of twice the mean annual speed, and for August a speed similar to the mean annual speed, decreasing to half the mean annual speed for September. The radar data are observed near the location of the maximum on the transverse profile, but should be lower than the mean annual speed owing to the seasonal variations. The radar data from 1 September show an increase in speed of $0.2 \mathrm{~m} \mathrm{~d}^{-1}$ over the last $150 \mathrm{~m}$ to the front. Thus the speed $1 \mathrm{~km}$ up-glacier from the front may be substantially lower than the measured speed at $2.5 \mathrm{~m}^{-1}$ at the front. Therefore, the radar data are certainly within the range of previously measured interannual and seasonal variations $1 \mathrm{~km}$ further up-glacier.

The calving event at $1009 \mathrm{~h}$ on 30 August is recorded by the video. Thus, the sudden increase in range to the strong reflecting front observed in the radar record at that time can be associated with calving. A similar increase in range later the same day is also attributed to calving. Video images are not required for identification of calving events, but were useful to support the first interpretation.
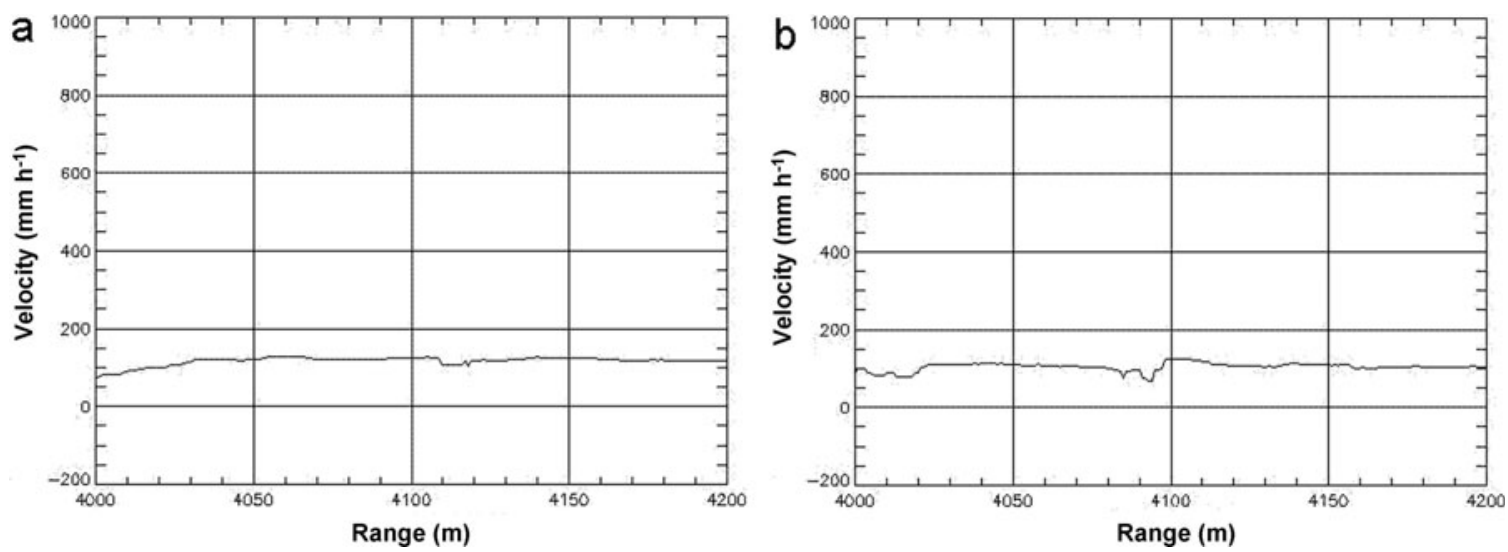

Fig. 8. Spatial variation in a velocity over 4000-4200 m: (a) 1300-1400 h, 1 September 2007; and (b) 2200-2300 h, 1 September 2007. 

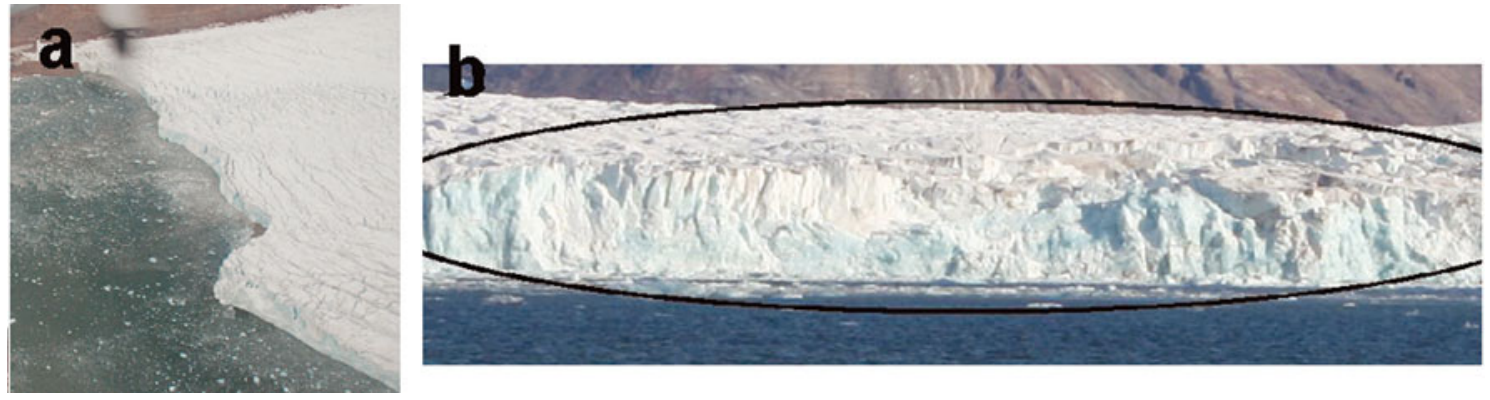

Fig. 9. Photographs of the calving front: (a) aerial photograph and (b) terrestrial photograph of measurement area.

During the fieldwork we observed large transverse surface crevasses, isolating blocks of ice that we expected to calve (Fig. 9). Generally, final failure occurred not along the initial crevasse but rather between that crevasse and the ice front. Several failures occurred before the crevasse was finally reached. The strain rate of the ice, derived from the movement of $600 \mathrm{~mm} \mathrm{~h}^{-1}$ over a distance of $10 \mathrm{~m}$ on 29 August (Fig. 7C), implies a stress far beyond the tensile stress for fracture of ice of $90-320 \mathrm{kPa}$ (Vaughan, 1993). The measured speed-up of this $30 \mathrm{~m}$ slab of ice near the glacier front may be explained by rotation due to longitudinal (along-glacier flow) widening of a transverse crevasse. This crevasse was not observed in the field, but its presence may be confirmed by terrestrial stereophotogrammetry, from which data have yet to be processed. The position of the crevasse must have been at least $32 \mathrm{~m}$ up-glacier from the front position before the two calving events occurred on that day, or up-glacier of a range of $4042 \mathrm{~m}$ (Fig. 4a). The two major calving events on that day resulted in removal of $25 \mathrm{~m}$ of ice in the radar range direction. The velocity returned to its background velocity of $2.5 \mathrm{~m} \mathrm{~d}^{-1}$ by $1530 \mathrm{~h}$ after the calving events.

During the fieldwork we also observed that there were large variations in calving activity. There can be several calving events during an hour or over a day, while another day can be without any events. The locations of the calving also vary: while it is uneventful at the measurement site, there may be a large number of calving events in other parts of the glacier front. This is in agreement with the two data series we have presented: there are two major calving events during 29-30 August, while on 1 September the velocity is stable and no events are registered in the radar data.

\section{CONCLUSIONS}

Some rudimentary tests using different polarizations did not indicate a favourable polarization of the antennas, but we recommend that measurements are carried out with the same polarizations during an entire campaign to facilitate comparison of the data.

There are coherent radar targets (permanent scatterers) on a glacier surface that can be tracked to determine ice velocity at different distances from the radar. However, when the position of the strongest scatterer for the specific range cell shifts to another range cell, the tracking is lost and the interferometric distance becomes corrupted by noise.

When permanent scatterers can be tracked over stable periods, the accuracy of the determined movements is expected to be within some hundreds of $\mathrm{mm} \mathrm{d}^{-1}$, while the relative movement on the glacier may be measured to some $\mathrm{mm} \mathrm{d}^{-1}$ accuracy. The accuracies can be verified by placing a stable corner reflector on the opposite side of the fjord from the radar, and moving reflectors on the glacier.

Major calving events can be readily identified in the radar data from sudden steps in the range to the strongly reflecting calving front. Video data are not necessary to identify calving events, but one major calving event is confirmed by the video recordings. A total of $25 \mathrm{~m}$ of ice in the radar range direction calved off during a 5 hour period, in two large events. We find that there are periods of hours with high calving rates, and periods with calm and stable conditions.

The data show that calving events do not influence the speed further up-glacier. The measured velocities are stable $150 \mathrm{~m}$ up-glacier from the front. However, we measured an increase in the velocity of ice within $30 \mathrm{~m}$ from the front, starting before the calving event. After the calving event the velocity returned to its pre-calving value. The large increase in speed may be due to widening of a transverse surface crevasse. This explanation will be tested by analysis of terrestrial photogrammetry conducted during the period. After the two calving events, the velocity returned to a stable $2.5 \mathrm{~m} \mathrm{~d}^{-1}$. The measured velocities are in agreement with previous measurements.

We believe that these types of radar data can contribute to an improved understanding of second-order calving processes, as they give spatially continuous (every $1 \mathrm{~m}$ ) velocities in the radar range direction at a high temporal rate, and also the depth of the calving blocks. Terrestrial photogrammetry, which provides daily terrain models and crevasse positions near the front, aids interpretation.

Ground-based interferometric radar is a useful and promising technique for velocity and calving-rate measurement of a calving front. The radar can be placed at a safe distance from the calving ice blocks, and still provide accurate measurements of the glacier front velocity.

\section{ACKNOWLEDGEMENTS}

The fieldwork was supported by 'Innovasjon Norge' and Svalbard Science Forum. The work is part of the International Polar Year project GLACIODYN, funded by the Norwegian Research Council.

\section{REFERENCES}

Abdalati, W. and W.B. Krabill. 1999. Calculation of ice velocities in the Jakobshavn Isbræ area using airborne laser altimetry. Remote Sens. Environ., 67(2), 194-204. 
Benn, D.I., C.W. Warren and R.H. Mottram. 2007. Calving processes and the dynamics of calving glaciers. Earth-Sci. Rev., 82(3-4), 143-179.

Bentley, C.R. and M.B. Giovinetto. 1991. Mass balance of Antarctica and sea level change. In Weller, G., C.L. Wilson and B.A.B. Severin, eds. Proceedings of International Conference on the Role of the Polar Regions in Global Change, Vol. 2. Fairbanks, AK, University of Alaska, 481-488.

Bigg, G.R. 1999. An estimate of the flux of iceberg calving from Greenland. Arct. Antarct. Alp. Res., 31(2), 174-178.

Brown, C.S., M.F. Meier and A. Post. 1982. Calving speed of Alaska tidewater glaciers, with application to Columbia Glacier. USGS Prof. Pap. 1258-C, C1-C13.

Elósegui, P. and 11 others. 2007. Geodetic measurements and analysis of glacier kinematics in east Greenland. EOS, 88(52), Fall Meet. Suppl., Abstract G33C-02.

Goldstein, R.M., H. Engelhardt, B. Kamb and R.M. Frolich. 1993. Satellite radar interferometry for monitoring ice sheet motion: application to an Antarctic ice stream. Science, 262(5139), 1525-1530.

Graham, L.C. 1974. Synthetic interferometer radar for topographic mapping. Proc. IEEE, 62(6), 763-768.

Hanson, B. and R.LeB. Hooke. 2000. Glacier calving: a numerical model of forces in the calving-speed/water-depth relation. J. Glaciol., 46(153), 188-196.

Hanson, B. and R.LeB. Hooke. 2003. Buckling rate and overhang development at a calving face. J. Glaciol., 49(167), 577-586.

Hanssen, R.F. 2001. Radar interferometry: data interpretation and error analysis. Dordrecht, etc., Kluwer Academic Publishers.

Howat, I.M., I. Joughin, S. Tulaczyk and S. Gogineni. 2005. Rapid retreat and acceleration of Helheim Glacier, east Greenland. Geophys. Res. Lett., 32(22), L22502. (10.1029/2005GL024737.)

Hughes, T. 1986. The Jakobshavns effect. Geophys. Res. Lett., 13(1), 46-48.

Joughin, I. 2002. Ice-sheet velocity mapping: a combined interferometric and speckle-tracking approach. Ann. Glaciol., 34, 195-201.

Joughin, I. and D.R. MacAyeal. 2005. Calving of large tabular icebergs from ice shelf rift systems. Geophys. Res. Lett., 32(2), L02501. (10.1029/2004GL020978.)

Kääb, A., B. Lefauconnier and K. Melvold. 2005. Flow field of Kronebreen, Svalbard, using repeated Landsat 7 and ASTER data. Ann. Glaciol., 42, 7-13.

Krimmel, R.M. 2001. Photogrammetric data set, 1957-2000, and bathymetric measurements for Columbia Glacier, Alaska. USGS Water-Resour. Invest. Rep. 01-4089.

Lefauconnier, B., J.O. Hagen and J.P. Rudant. 1994. Flow speed and calving rate of Kongsbreen glacier, Svalbard, using SPOT images. Polar Res., 13(1), 59-65.

Massonnet, D., P. Briole and A. Arnaud. 1995. Deflation of Mount Etna monitored by spaceborne radar interferometry. Nature, 375(6532), 567-570.

Meier, M.F. and A. Post. 1987. Fast tidewater glaciers. J. Geophys. Res., 92(B9), 9051-9058.

Melvold, K. 1992. Studie av brebevegelse på Kongsvegen og Kronebreen, Svalbard. Oslo, Universitetet i Oslo. (Rapportserie i Naturgeografi 1.)

Norland, R. 2006. Differential interferometric radar for mountain rock slide hazard monitoring. In IGARSS 2006. Proceedings of the International Geoscience and Remote Sensing Symposium,
31 July-4 August 2006, Denver, CO. Piscataway, NJ, Institute of Electrical and Electronics Engineers, 3293-3296.

Norland, R. 2007. Improving interferometric radar measurement accuracy using local meteorological data. In IGARSS 2007. Proceedings of the International Geoscience and Remote Sensing Symposium, 23-28 July 2007, Barcelona, Spain. Piscataway, NJ, Institute of Electrical and Electronics Engineers, 4521-4524.

Oerlemans, J. and F.M. Nick. 2005. A minimal model of a tidewater glacier. Ann. Glaciol., 42, 1-6.

O'Neel, S., W.T. Pfeffer, R. Krimmel and M. Meier. 2005. Evolving force balance at Columbia Glacier, Alaska, during its rapid retreat. J. Geophys. Res., 110(F3), F03012. (10.1029/ 2005JF000292.)

Pfeffer, W. 2004. Applications of modern digital terrestrial photogrammetry to problems in glaciology. Eos, 85(47), Fall Meet. Suppl., Abstract C42A-04.

Pillewizer, W. and U. Voigt. 1968. Block movement of glaciers. Geod. Geophys. Veröff. [Berlin] RIII.

Reeh, N., C. Mayer, H. Miller, H.H. Thomsen and A. Weidick. 1999. Present and past climate control on fjord glaciations in Greenland: implications for IRD-deposition in the sea. Geophys. Res. Lett., 26(8), 1039-1042.

Rignot, E. and P. Kanagaratnam. 2006. Changes in the velocity structure of the Greenland Ice Sheet. Science, 311(5673), 986-990.

Rolstad, C. 1995. Satellitt- og flybilder til bestemmelse av bredynamikk [Satellite- and aerial photographs for determination of glacier dynamics]. (MSc thesis, University of Oslo.)

Rolstad, C., J. Amlien, J.O. Hagen and B. Lundén. 1997. Visible and near-infrared digital images for determination of ice velocities and surface elevation during a surge on Osbornebreen, a tidewater glacier in Svalbard. Ann. Glaciol., 24, 255-261.

Scambos, T.A., M.J. Dutkiewicz, J.C. Wilson and R.A. Bindschadler. 1992. Application of image cross-correlation to the measurement of glacier velocity using satellite image data. Remote Sens. Environ., 42(3), 177-186.

Strozzi, T., U. Wegmuller, C. Werner and A. Wiesmann. 2002. Alpine landslide periodical survey. In IGARSS '02. 22nd International Geoscience and Remote Sensing Symposium, 24-28 June 2002, Toronto, Canada. Proceedings, Vol. 6. Piscataway, NJ, Institute of Electrical and Electronics Engineers, 3629-3631.

Theakstone, W.H. and N.T. Knudsen. 1986. Recent changes of a calving glacier, Austerdalsisen, Svartisen, Norway. Geogr. Ann., $\mathbf{6 8 A}(4), 303-316$

Ulaby, F.T. 2006. Fundamentals of applied electromagnetics. Fifth edition. Upper Saddle River, NJ, Prentice Hall.

Van der Veen, C.J. 1996. Tidewater calving. J. Glaciol., 42(141), 375-385.

Van der Veen, C.J. 2002. Calving glaciers. Progr. Phys. Geogr., 26(1), 96-122

Vaughan, D.G. 1993. Relating the occurrence of crevasses to surface strain rates. J. Glaciol., 39(132), 255-266.

Venteris, E.R., I.M. Whillans and C.J. van der Veen. 1997. Effect of extension rate on terminus position, Columbia Glacier, Alaska, USA. Ann. Glaciol., 24, 49-53.

Zebker, H.A. and R.M. Goldstein. 1986. Topographic mapping from interferometric synthetic aperture radar observations. J. Geophys. Res., 91(B5), 4993-4999. 